\title{
Clinical Audit of Genetic Testing and Referral Patterns for Fragile X and Associated Conditions
}

Megan Cotter ${ }^{1,2,3}$, Alison D Archibald ${ }^{1,2,4}$, Belinda J McClaren ${ }^{1,2}$, Trent Burgess ${ }^{2,4}$, David Francis ${ }^{4}$, Louise Hills ${ }^{4}$, Melissa Martyn ${ }^{1}$, Ralph Oertel ${ }^{4}$, Howard Slater ${ }^{2,4}$, Jonathan Cohen ${ }^{1,5}$, and Sylvia A Metcalfe ${ }^{1,2}$

\begin{abstract}
Affiliations: ${ }^{1}$ Genetics Education and Health Research, Murdoch Childrens Research Institute, Royal Children's Hospital, Parkville, VIC, Australia; ${ }^{2}$ Dept of Paediatrics, The University of Melbourne, Parkville, VIC, Australia; ${ }^{3}$ Clinical Genetics, Austin Health, Heidelberg, VIC, Australia; ${ }^{4}$ Victorian Clinical Genetics Services and Murdoch Childrens Research Institute, Parkville, VIC, Australia; ${ }^{5}$ Fragile X Alliance Inc, North Caulfield, VIC and Centre for Developmental Disability Health Victoria, Monash University, Clayton, VIC, Australia.
\end{abstract}

Address correspondence to: Sylvia A Metcalfe, Genetics Education and Health Research, Murdoch Childrens Research Institute and Department of Paediatrics, The University of Melbourne, Royal Children's Hospital, Flemington Rd, Parkville, VIC 3052, Australia, [sylvia.metcalfe@mcri.edu.au.], +61-3-8341-6309.

\section{Running heads:}

Cotter et al. (left-hand page)

Genetic Testing and Referrals for Fragile $\mathbf{X}$ (right-hand page) 


\begin{abstract}
An audit was conducted of laboratory/clinical databases of genetic tests performed between January 2003 and December 2009, and for 2014, as well as referrals to the clinical service and a specialist multidisciplinary clinic, to determine genetic testing request patterns for fragile $\mathrm{X}$ syndrome and associated conditions and referrals for genetic counseling/multidisciplinary management in Victoria, Australia. An expanded allele (full mutation, premutation or intermediate) was found in $3.7 \%$ of tests. Pediatricians requested $\sim 70 \%$ of test samples, although fewer general practitioners and more obstetricians/gynecologists ordered tests in 2014. Median age at testing for individuals with a full mutation seeking a diagnosis without a fragile $\mathrm{X}$ family history was 4.3 years (males) and 9.4 years (females); these ages were lower when pediatricians ordered the tests (2.1 years and 6.1 years respectively). Individuals with a premutation were generally tested at a later age (median age: males, 33.2 years; females, 36.4 years). Logistic regression showed that a family history of ID (OR $3.28 \mathrm{p}=0.005$, CI 1.77-5.98) was the only indication to independently increase the likelihood of a test-positive (FM or PM) result. Following testing, $\sim 25 \%$ of full mutation or premutation individuals may not have attended clinical services providing genetic counseling or multidisciplinary management for these families. The apparent delay in fragile $\mathrm{X}$ syndrome diagnosis and lack of appropriate referrals for some may result in less than optimal management for these families. These findings suggest continued need for awareness and education of health professionals around diagnosis and familial implications of fragile $\mathrm{X}$ syndrome and associated conditions.
\end{abstract}

Key words: fragile $\mathrm{X}$ syndrome; fragile $\mathrm{X}$-associated conditions; FMR1; genetic testing; diagnostic odyssey 


\section{INTRODUCTION}

Fragile X syndrome (FXS) is one of several disorders comprising FMR1 geneassociated conditions, with wide implications for inter-generational members of a family. FXS is caused by silencing of the FMRl gene when expansions of $>200$ CGG repeats (full mutation (FM)) are hypermethylated. The premutation (PM), 55-200 repeats, can expand to a FM when passed from mother to child and is associated with risk of fragile $\mathrm{X}$-associated primary ovarian insufficiency (FXPOI) [Sullivan et al., 2005], fragile X-associated tremor/ataxia syndrome (FXTAS) [Hagerman et al., 2001], and other more subtle neurobehavioral features [Kraan et al., 2014a and b]. It is estimated that about 1 in 200 females and 1 in 430 males are carriers of the PM [Tassone et al., 2012]. A small proportion of alleles in the intermediate or gray zone (GZ) range, 45-54 repeats, are also associated with instability but so far observed to expand only to the PM range [Nolin et al., 1996 and 2003]. The potential clinical significance of GZ alleles is currently under investigation [Loesch et al., 2009A and 2009B].

Although FMR 1-associated conditions are not curable, timely diagnosis through genetic testing is important as it can lead to implementation of treatment strategies and behavioral interventions considered to improve symptoms [Hagerman et al., 2009]; knowledge of expanded allele status for women can inform reproductive decision-making [Hill et al., 2010]. Guidelines recommend FMR1 DNA testing for individuals with: 1) intellectual disability, developmental delay or autism; 2) reproductive or fertility problems associated with elevated FSH levels; 3 ) individuals with late onset tremor or cerebellar ataxia of unknown origin; 4) individuals with a family history of any of the above [Sherman et al., 2005; Hersh and Saul, 2011; Finucane et al., 2012; Human Genetics Society of Australasia, 2012]. Despite these guidelines, families in the USA appear to experience delays in receiving a diagnosis of FXS: parents reported varying timeframes between the initial identification of 
developmental delay and a diagnosis of FXS [Bailey et al., 2003], on average 35-37 months of age (2.9-3.1 years) for males and 41.6 months of age (3.5 years) for females [Bailey et al., 2009]. Furthermore, $25 \%$ of families with a male previously diagnosed with FXS had another child with FXS before the initial diagnosis occurred [Bailey et al., 2009]. Delays in diagnosing FXS may be in part due to non-specific features and phenotypic variation. Delayed diagnoses of FXS may also be due to a general lack of awareness of the condition by healthcare professionals [Kemper et al., 2009]. Hersh and Saul [2011] detailed the role of pediatricians in the health supervision of children with FXS. They also emphasized the importance of genetic counseling, management by a multidisciplinary team and referral to appropriate support organizations, particularly in the context of the variable clinical phenotypes of FMR1-associated conditions and their impact on multiple generations within a family. Therefore it is important to understand how testing of individuals presenting with relevant clinical indications, and management of families, occur in clinical practice. Here we report findings from an audit of FMRl genetic testing and referral patterns for genetic and clinical management in Victoria, Australia, over a seven year period during which genetic services in this state were centralized, enabling access to a discrete dataset. For comparison of patterns of requests for testing, genetic tests performed in the most recent year were also included.

\section{MATERIALS AND METHODS}

\section{Setting}

During 2003 and 2009, the genetic testing laboratory of the Victorian Clinical

Genetics Services (VCGS) was the major provider ( $>90 \%$ ) of FMR1 testing in the State of Victoria, Australia. FMR1 testing was performed by polymerase chain reaction (PCR) (amplifying repeat sequences up to $\sim 110$ repeats), followed by Southern blot analysis to 
confirm or determine PM or FM alleles when required; for example, when PCR amplification failed to show an allele in males or when only one allele was seen in females, and therefore reported as an inconclusive PCR result. Only the VCGS laboratory performed Southern blots for FMR1 testing in Victoria [Fu et al., 1991]. In Australia, patients who visit a pediatrician (community- or hospital-based) or other specialist physician must be referred by a patient's general practitioner (GP). Prior to 2003 only specialist physicians could order a genetic test for FXS. Since 2003, the cost of FMRl testing for diagnostic purposes was subsidised by the Australian federal government through the Medicare Benefits Schedule (MBS)[Medicare.] allowing the test to be ordered by any clinician, including GPs. Individuals found to have an expanded allele (FM, PM) are recommended for referral to genetics services for genetic counseling [Human et al., 2012], while VCGS also recommends this referral for GZ results. VCGS receives state Department of Health funding to provide genetic counseling and management of the genetic implications associated with FMRI-associated conditions. In Victoria, a specialized clinic [Fragile X Alliance Inc. (FXA)] conducts a multidisciplinary clinic that provides support and clinical/genetic management to families with a history of FXS. Children and adults with FXS seen at the FXA clinic receive an assessment which includes a medical consultation, audiology, optometry, occupational therapy, speech and psychological assessments. This is a privately funded assessment for which there is usually some subsidy available from the parents support group [Fragile X Association Australia].

\section{Ethics}

Ethics approval was obtained from the Human Research Ethics Committee (HREC) of the Royal Children's Hospital, Melbourne and registered with the University of Melbourne HREC.

\section{Data Collection}


Two data sources were collected:

(1) All FMR1 genetic tests performed by VCGS laboratory during January 2003 to December 2009. To check for any recent changes to testing requests, tests performed in 2014 were also included for comparison. These included diagnostic tests performed on individuals identified through carrier screening (introduced by a number of pathology services from 2012), but do not include the actual number of screening tests requested.

(2) Referrals to clinical services (VCGS and FXA) following an expanded FMR1 allele result (i.e. FM, PM) were identified during 2003 to 2009. Equivalent data for 2014 were not included as genetic services were de-centralized after 2009, making crossreferencing difficult.

The following information in the laboratory database was obtained for each individual who had FMR1 genetic testing: first name, last name, date of birth, gender, date the sample was received, clinical indications for testing as noted on the request form, test result (i.e. FM, PM, GZ, normal, inconclusive), sample type, name and clinic details of health practitioner requesting testing, and a requester code unique to VCGS. The data required cleaning and some further coding, such as the clinical indications for testing, the age at testing and requesting health practitioner specialty.

Clinical data were collected from VCGS and FXA by searching their respective electronic databases/patient files for all individuals with an FMRl expansion (FM, PM, GZ) documented as attending during the relevant period, and cross-matched with the VCGS laboratory database.

Data were extracted between January and September 2010, and May 2015.

\section{Data Analysis}


Information obtained from VCGS and FXA was entered into a Microsoft Access database and analyzed in Microsoft Excel and Stata 13.

\section{RESULTS}

\section{Tested Sample}

Between January 2003 and December 2009, VCGS performed 19,861 FMR1 genetic tests (Figure 1). Testing was conducted for various clinical reasons (seeking a diagnosis of FXS, eg for developmental delay, autism, intellectual disability, etc, seeking a diagnosis of FXPOI or FXTAS (PM phenotypes), carrier testing and/or cascade testing for a family history of FXS), prenatal testing, quality assurance, and research purposes. After prenatal testing, quality assurance and research tests were excluded, 12,251 individuals remained for whom a date of birth was recorded and referred by a health practitioner based in Victoria, with males comprising $69.8 \%$ of the tested population. Most results $(n=11,798)$ were classified as "normal", "inconclusive" or "unclear", with these last two categories then undergoing further Southern blot testing for final determination. The number of individuals tested per year was fairly constant between 2003 and 2006 ( 1600 to 1700), increasing to $\sim 1900$ in 2008 and 2009. Between 2003 and 2009 there were 453 individuals identified with an expanded FMR1 allele result, comprising $3.7 \%$ of the population $(12,251)$ tested: $0.6 \%$ had a FM result; $1.5 \%$ had a PM result; and $1.5 \%$ had a GZ result (Figure 1). For comparison, in 2014 there were 2,423 individuals ( $64.8 \%$ males, $35.0 \%$ females) tested. Of these, $96(4.0 \%)$ had an expanded FMR1 allele result: $14(0.6 \%)$ had a FM result, while 3 (0.1\%) were FM/PM size mosaic (therefore, $0.7 \%$ combined); $39(1.6 \%)$ and $40(1.7 \%)$ had a PM or GZ result respectively. There was no evidence of a difference in these proportions of test-positive results between the years tested (all expanded alleles: $p=0.48 ; F M, p=0.57 ; P M$, $\mathrm{p}=0.71 ; \mathrm{GZ} ; \mathrm{p}=0.58 ;$ student $\mathrm{t}$-test $)$. 


\section{Health Practitioners Requesting FMR1 Tests}

Between 2003 and 2009 there were 1048 individual health practitioners practicing in Victoria whose specialty could be determined and who requested a FMR1 genetic test, with $513(49.0 \%)$ ordering a test for more than one patient (Table I). Of 12,251 individuals tested, there were 259 (2.1\%) for whom their health practitioner's specialty could not be identified. Pediatricians requested the greatest number of tests (number of tests $=8424,68.8 \%$ ), with 151 requesting tests for $>10$ patients (Table I). Although GPs ordered fewer tests (number of tests $=1072,8.8 \%$ ), more GPs overall requested tests, with 362 individual GPs (ie, $73.4 \%$ of GPs) ordering only a single test (Table I). Genetic health professionals ordered 852 tests (7.0\%) and various other medical specialties ordered 955 tests $(7.8 \%)$. The remaining $7.7 \%$ ( $n=946)$ of tests were referred by other pathology services which performed the initial PCR test but then referred to VCGS for Southern blot analysis. Details of the original requesting health practitioners for these individuals could not be obtained due to privacy reasons. In 2014, there were some differences in testing requests: there is strong evidence of an increase in tests requested by pediatricians $(72.1 \%$; $p<0.002$; student t-test) and fewer (all $p<0.001)$ by GPs $(6.0 \%)$, genetic health professionals $(5.0 \%)$ and pathologists $(1.1 \%)$ - the last probably reflects more private pathology laboratories performing these tests. Tests requested by obstetricians/gynecologists increased from $2.4 \%$ during $2003-2009$ to $11.8 \%(p<0.001)$, although it should be noted that one particular obstetrician/gynecologist ordered almost 70\% of these; nevertheless the increase $(3.7 \%)$ is still significant $(\mathrm{p}<0.001)$.

Further analysis of those with an expanded allele $(n=453)$, was performed, and FM and PM results are presented. Of those in which the clinical indication for testing was consistent with "seeking a diagnosis of FXS" (ie. FXS, a family history of FXS or a feature of FXS were specifically mentioned), 68 were FM results, with 25 of these indicating testing was performed as part of family cascade testing. Pediatricians ordered $39.7 \%(n=27)$ and GPs 
$30.1 \%(n=21)$ (Table II). The remaining 29.4\% $(n=20)$ were requested by other medical specialties including geneticists and obstetrician/gynecologists (Table II). Eleven (13.9\%) FM results were found in individuals who were tested for carrier status, with eight of these as part of family cascade testing. In 2014, of the $14 \mathrm{FM}$ and $3 \mathrm{FM} / \mathrm{PM}$ results, $70.5 \%(\mathrm{n}=12)$ were seeking a diagnosis of FXS, with $29.5 \%(n=5)$ cascade tested; a further $29.5 \%(n=5)$ were cascade tested for carrier status. Geneticists ordered 35.3\%, pediatricians 29.4\%, GPs and obstetricians/gynecologists equally requested the remaining $(n=6)$.

Of the tests generating185 PM results, genetic health professionals ordered 50.3\%, GPs $20.0 \%$, pediatricians $13.5 \%$, obstetricians/gynecologists $6.5 \%$ and neurologists $2.2 \%$ (Table III). The majority $(60.5 \%, \mathrm{n}=112)$ of PM results were requested for seeking PM carrier status (cascade testing). Thirty-six individuals (19.5\%) for whom the clinical indication suggested seeking a diagnosis of FXS received a PM result, with ten cascade tested. Sixteen $(8.7 \%)$ individuals received a PM result for whom the clinical indication was PM-specific phenotype (Table III). By comparison, in 2014 the 39 PM results were requested by pediatricians $(28.2 \%)$, obstetricians/gynecologists $(25.6 \%)$, geneticists $(23.1 \%)$, GPs $(18.0 \%)$ and others specialties $(5.1 \%)$.

\section{Age at Testing}

The median age at testing for all 12,251 individuals was 5.2 years (males, 4.7 years; females, 8.3 years). The range of age at testing was $<1$ week to 89.9 years; the numbers tested at all ages show a bimodal distribution (Figure 2A). In 2014, the median age at testing for all 2,423 individuals tested was 5.9 years (males, 5.1 years; females, 11.8 years).

The median age at testing was also calculated for individuals with a FM who were tested to diagnose FXS or for carrier testing, noting when cascade testing occurred. Of the 33 females with a FM result, 22 were tested for diagnostic purposes and 11 for carrier testing. 
For all 68 individuals with a FM result who were tested for diagnostic reasons (including cascade), the median age overall was 11.4 years (range $=<0.1-54.8$ years):12.4 years for males $(n=46)$ and 11.1 years for females $(n=22)$ (Table II). The numbers of FM results over this age range are shown in Figure 2B.

As seen in Table II, the median age at testing for FM individuals who were referred by pediatricians was 3.2 years (range=1.0-38.1 years; $n=28$ ), with a higher median age for females than males (6.1 years (range $=1.8-38.1$ years; $n=10)$ and 2.4 years $($ range $=1.0-8.8$ years; $n=18$ ) respectively). One of these females was carrier cascade tested; if this mother is excluded, the median age at testing changes to 5.3 years for females. The median age at testing for FM individuals who were referred by GPs was 34.2 years (range=11.75-52.7 years; $n=21$ ) and were predominantly male. 2014 testing showed that the overall median age of testing for those with a FM or FM/PM result was 26.3 years (range=<0.1-54.2 years), with a median of 4.3 years for males (range $=<0.1-54.2$ years, $n=9$ ) and 31.5 years for females (range=2.9-47.9 years, $n=8)$. Seeking a diagnosis was noted for $70.5 \%(n=12)$ of FM results, with carrier cascade testing in $29.5 \%(n=4$, all females). When pediatricians requested the tests, the median age was 2.3 years (range $=1.5-4.3$ years, $n=3$ males and 1 female) when seeking a diagnosis of FXS.

Table III shows the median age at testing of individuals with a PM result (overall age $=36.1$ years, range $=<0.1-89.9$ years, $n=185$ ). The numbers of $P M$ results over this age range are shown in Figure 2B. Testing for these individuals with no FXS family history showed a median age for males of 3.8 years, (range $=<0.1-61.5 .0$ years, $n=21), 3.2$ years for females (range 1.4-17.4 years, $n=5)$; cascade testing of males was 4.1 years $(n=5)$ and females 5.4 years $(n=5)$ (see Table III).). Requests for cascade carrier testing comprised the major part of PM results (median age at testing for females $=40.0$ years $($ range $=16.8-89.9$ years, $n=88)$ and males $=44.5$ years $($ range $=21.3-60.9$ years, $n=24)$. 
Overall median age at testing to seek a diagnosis of a PM phenotype, either FXTAS or FXPOI, was 40.2 years (range $=18.8-73.7$ years, $n=16$ ): median age for females tested for FXPOI $=28.1$ years $($ range $=18.8-43.7$ years, $n=9) ;$ median age for individuals tested for FXTAS $=65.7$ years (range $=60.0-73.7$ years, $n=7$ comprising 5 males and 2 females $) .2014$ data showed that the overall median age at testing of 39 individuals with a PM result was 34.4 years (males, 8.25 years, $n=9$; females, 35.4 years, $n=30$ ). Carrier testing accounted for $66.7 \%(n=26)$ of these (10 from carrier screening and 16 carrier cascade testing; median age $=36.1$, 24 females, 2 males), seeking a diagnosis of FXS in $20.5 \%$ ( $\mathrm{n}=8$, including one cascade testing) and $12.8 \%(\mathrm{n}=5)$ for PM-specific phenotype testing.

To investigate whether there were any factors associated with test-positive results we performed univariate and multivariate logistic regression, examining reasons for testing (including family history) and doctor specialty. We re-categorised reasons for testing (as noted on the request form) into: FXS(?/query), intellectual disability (ID), developmental delay (DD), autism spectrum disorder (ASD), neurological symptoms, infertility symptoms, family history of FXS, family history of ID, family history of DD and family history of ASD. We found that the only indication which independently increased the likelihood of a testpositive (FM or PM) result was a family history of ID (OR $3.28 \mathrm{p}=0.005$, CI 1.77-5.98). If GZ is also included as part of the test-positive results, then FXS(?/query) (OR $2.47 \mathrm{p}=0.0119$ $\mathrm{CI}=1.93-3.16$ ), ID (OR $1.31 \mathrm{p}=0.0012$, CI 1.02-1.69), a family history of FXS (OR 3.65 $\mathrm{p}=0.006, \mathrm{CI}=2.31-5.76)$ and a family history of $\mathrm{ID}(\mathrm{OR} 2.94 \mathrm{p}=0.004, \mathrm{CI}=1.81-4.76)$, are independent predictors. Multivariate modelling retains FXS(?/query) (OR $2.25 \mathrm{p}<0.001$, CI 1.70-2.97), family history of FXS (OR $1.71 \mathrm{p}=0.043$, CI 1.02-2.87) and family history of ID $(\mathrm{OR} 3.06 \mathrm{p}<0.001 \mathrm{CI}, 1.87-4.99)$ as predictive for FM, PM or GZ results with $\mathrm{p}=0.0175$. No other factors, including specialty of the referring doctor, were predictive.

Post-testing Referrals to Clinical Services for Genetic Counseling and/or Management 
VCGS laboratory reports sent to the requesting health practitioner include a recommendation for genetic counseling for any individual with an expanded FMRI allele. During the timeframe, $38.0 \%(n=30)$ of individuals identified in the audit with a FM were seen by clinical staff (a geneticist and/or genetic counselor) at VCGS, 20.3\% $(n=16)$ were seen at FXA and $19.0 \%(n=15)$ were seen by both services. $22.8 \%(n=18)$ were not seen by either of these clinical services. For individuals with a PM, 66.0\% $(n=132)$ were seen by VCGS, 3.2\% $(n=6)$ were seen by FXA, $2.2 \%(n=4)$ were seen by both services and $28.7 \%$ $(n=53)$ were seen by neither service. There was no evidence of a difference between the percentages of individuals with FM (22.8\%) or PM (28.7\%) who were not seen at either of these services (Pearson chi-squared test, $\mathrm{p}=0.256$ ). Examination of post-testing referrals for 2014 was not possible due to the decentralization of genetic services.

\section{DISCUSSION}

A diagnosis of FXS affects the individual receiving the diagnosis and also their family members, as it may lead to identification of other relatives with a FM or a PM. A PM allele confers reproductive and FXPOI risks for women [Sullivan et al., 2005], as well as a higher risk of psychosocial issues [Kraan et al., 2014A and 2014B] and a significantly high risk of FXTAS for men [Hagerman et al., 2001]. Therefore, understanding referral pathways for individuals tested for FMR1 is important in ensuring that families receive the best care regarding the genetic implications of the test result. To our knowledge, this is the first study to examine laboratory and clinical record data exploring genetic testing, and provision of genetic counseling and management to individuals with FMRl expansions.

Overall, the median age at testing between 2003 and 2009 for all individuals was 5.2 years, and was comparable in 2014 at 5.9 years. During this timeframe, $0.6 \%$ of individuals tested received a FM result, which did not change in 2014, although a further $0.1 \%$ received a FM/PM mosaic result. The proportion of PM and GZ results $(\sim 1.5 \%$ each $)$ was similar in 
2014 (1.6\% and $1.7 \%$, respectively). The reason for testing is obviously important when examining age at testing. The median age at testing of individuals receiving a FM result between 2003 and 2009, for whom the clinical indications were seeking a diagnosis in the absence of a family history of FXS, was 4.3 years for males and 9.4 years for females, while the age for cascade testing was 28.7 years for males and 16.7 years for females (Table II). Although the 2014 data included fewer numbers, for males with a FM this was also 4.3 years.

The age at testing for this category of clinical indications also varied depending on the specialty of the referring health practitioner: the median age at testing was lowest when requested by a pediatrician (2.1 years for males and 6.1 years for females, in the absence of a family history). Pediatricians ordered the largest number of tests and appropriately ordered testing to diagnose (or exclude) FXS, with greater than $50 \%$ requesting tests for $>10$ individuals. Unfortunately it is not possible to estimate what proportion this represents of pediatricians practicing in Victoria, but there was a mix of community and hospital-based pediatricians. In the Australian healthcare context, children with developmental delay are typically referred to pediatricians so it is reasonable to expect that the majority of requests would be made by this specialty, despite GPs being able to request a FXS test on the MBS. It is interesting that in the earlier timeframe there was a large number of individual GPs ordering the test in a single instance, while the proportion of tests ordered by GPs decreased from $8.8 \%$ to $5.6 \%$ in 2014 . This decrease could reflect more GP referrals to pediatricians, or a reluctance to order the test again if their experience was receiving a negative result.

Also of note, the median age at testing for females with a FM in the absence of a family history of FXS was higher than for males (Table II), even when pediatricians ordered the test. Diagnosing FXS can be a difficult process as the physical features are highly variable [Lachiewicz et al., 2000] and developmental delay, relatively common in the general population [Bellman et al., 2013], is often the first indication that something is wrong. In 
Australia, the indications for FMRI testing on the MBS are: (a) the patient exhibits intellectual disability, ataxia, neurodegeneration or premature ovarian failure consistent with a FMR1 mutation; or (b) the patient has a relative with a FMR1 mutation [Medicare]. Furthermore, current guidelines recognise that these are broad terms and that patients can present with subtle features around learning disability, etc and that physical characteristics (such as large ears, macroorchidism, etc) may not be readily apparent, especially prepubertally [Hersh and Saul, 2011; Human Genetics Society of Australasia, 2012]. Given such variability in clinical presentation and the finding that only a family history of intellectual disability was predictive of a FM/PM result, it is perhaps not surprising that $<1 \%$ of test samples were identified with a FM. As such, it is likely many referring practitioners order FMR1 testing to exclude as much as diagnose FXS. In this regard, it is possible FMR1 testing might be acting as a form of 'screening' for children presenting with these non-specific features of developmental delay/intellectual disability, and indeed FXS testing is one of the range of tests (including chromosomal, currently microarrays, and metabolic) typically recommended for children with developmental delay. This type of screening for FXS has been discussed as an option by Abrams and colleagues, although they would argue that testing should occur earlier in childhood and note that this approach "is likely to miss many affected girls and some mildly affected boys" (Abrams et al, 2012). The findings from our audit contribute to the debate and policy discussions about different forms of screening for FMR1-related conditions, including population carrier screening and newborn screening. A USA survey explored pediatricians' knowledge of FXS [Kemper et al., 2009]. Of 165 respondents, most knew that FXS causes intellectual disability and were also aware of the delay in diagnosis that can occur with FXS. However, only half were aware that females could be affected with FXS and only a quarter knew there were clinical implications associated with PM status [Kemper et al., 2009]. It is also important to highlight in our audit 
that almost $20 \%(n=36)$ of individuals who received a PM result were tested to diagnose FXS. This is significant because it is now acknowledged that individuals with a PM may have some learning or behavioral difficulties [Kraan et al., 2014A and 2014B]. We do not know if the referring practitioners in this audit realised that these features can be present in someone who has a PM. We also note that 10 of these 36 individuals had a family history of FXS, while $70 \%$ of this group were seen by VCGS and/or FXA post-testing for management and counseling. There has been little research of health professionals' knowledge of FXS and its associated conditions in Australia. An early report highlighted a lack of awareness of FXS clinical features by GPs and speech pathologists [Cohen and Loesch, 1999] and findings from a recent qualitative study suggest that non-genetics healthcare providers have limited knowledge and awareness of FXS [Archibald et al., 2013].

A parent-reported survey from the USA found that a diagnosis occurs on average at 38.7 months ( $\sim 3$ years) for males and 41.6 months (3.5 years) for females, with $33 \%$ of the tests ordered by a family doctor, pediatrician or developmental pediatrician [Bailey et al., 2009]. The parent-reported length of time between concern about the child's development and diagnosis of FXS was 24 months. Based on the median age at testing for males and females with a FM result, our audit suggests there may also be a delay in diagnosis in Australia. In a survey conducted by the Fragile X Association of Australia, parents self-reported an average age of 66 months ( 5.5 years, $n=183$ ) for diagnosis of FXS (FM and PM, males and females) between 2006 and 2009 which mirrors our findings [Fragile X Association Australia, 2009]. Such delays can have multiple implications for a family in terms of the psychosocial impacts of the 'diagnostic odyssey', reproductive risks for females and management issues for individuals with a FM or PM. Regardless of the sex of the child, early diagnosis of FXS is paramount as it is beneficial for the affected individual and the family [Bailey et al., 2003]. 
With the introduction of carrier screening panels in Victoria that include FMR1 testing [Victorian Clinical Genetics Services, 2011], more obstetricians/gynecologists seem to be undertaking carrier screening of women for reproductive decision-making, as well as for FXPOI when indicated. Notably, there was a paucity of testing for FXTAS by neurologists.

It is not clear to what extent pediatricians or other non-genetic health professionals are aware of the multigenerational, multiphenotypic nature of expansions in the FMRI gene. Most ( $75 \%)$ of individuals with a PM or FM result were seen by either VCGS or the FXA and therefore are expected to be informed about the genetic risks associated with an expanded FMR1 gene expansion. The remaining individuals with a PM or FM result, however, were not recorded as having been seen by either of these organizations following the testing, although in the case of cascade testing other family members may have attended previously. It is not apparent whether requesting health professionals are discussing the genetic implications for these individuals and their families, or if patients have not received any or adequate genetic information about FMRl-associated conditions.

\section{Limitations of the Research}

Analysis of the clinical indications for testing relied on coding into broad categories, requiring some interpretation of the clinical indications entered in the VCGS laboratory database by staff. VCGS and/or FXA may see more FXS families than indicated; however, the numbers reported herein are only for those tested by VCGS during the specific timeframe and for whom the visits were documented in the clinic databases/files. On the other hand, one advantage to this audit is that during 2003-2009 this single laboratory performed the vast majority of tests for FMR1 in Victoria, and the two clinical services were the predominant providers of genetic counseling and/or genetic management of families with an expanded 
FMR1 allele. The age at testing data for 2014 are not notably different, suggesting that the findings are likely representative of testing and referral patterns in Victoria. However, these data are confined to testing in Victoria, Australia and, as such, cannot be generalized to other settings.

\section{Conclusion}

Based on the median ages at testing and finding a FM result, these audit data indicate an apparent delay in diagnosis of FXS in Victoria, Australia. When pediatricians ordered the test, the age at testing for males is comparable to USA data, but is higher for females and higher still when other health professionals requested the test. Given the risk of FXPOI, median age at testing of females with a PM result seems also to be high. Coupled with an apparent lack of appropriate referrals for discussion of the genetic and clinical implications in up to a quarter of individuals with expanded FMRI alleles, these individuals and families may not be receiving optimal management. We could not ascertain whether non-genetic health professionals requesting testing discussed the genetic and familial implications of the expanded FMRI allele result with their patients. Future research could investigate health practitioners' knowledge of the FMRl spectrum of disorders, management recommendations and services available in Australia, to inform educational strategies and clinical practice.

\section{ACKNOWLEDGEMENTS}

We thank Vicki Petrou, Jean Paul and Mark Adams for assistance with ascertaining requesting doctors' specialties. This study was completed in partial fulfilment of the requirements for the Master of Genetic Counselling, The University of Melbourne, Victoria, Australia and was supported by the Victorian Government's Operational Infrastructure Support Program. The authors declare they have no conflict of interest to disclose. 
2 


\section{REFERENCES}

Abrams L, Cronister A, Brown WT, Tassone F, Sherman SL, Finucane B, McConkie-Rosell A, Hagerman R, Kaufmann WE, Picker J, Coffey S, Skinner D, Johnson V, Miller R, Berry-Kravis E. 2012. Newborn, carrier and early childhood screening recommendations for fragile X. Pediatrics130:1126-1135.

Archibald AD, Hickerton CL, Jaques AM, Wake S, Cohen J, Metcalfe SA. 2013. "It's about having the choice": stakeholder perceptions of population-based genetic carrier screening for fragile X syndrome. Am J Med Genet Part A 161A:48-58.

Bailey DB, Jr., Raspa M, Bishop E, Holiday D. 2009. No change in the age of diagnosis for fragile x syndrome: findings from a national parent survey. Pediatrics 124:527-533.

Bailey DB, Jr., Skinner D, Sparkman KL. 2003. Discovering fragile X syndrome: family experiences and perceptions. Pediatrics 111:407-416.

Bellman M, Byrne O, Sege R. 2013. Developmental assessment of children. BMJ 346:e8687.

Cohen J, Loesch DZ. 1999. Fragile X syndrome: do professionals know about it? Med J Aust 170:624.

Finucane B, Abrams L, Cronister A, Archibald AD, Bennett RL, McConkie-Rosell A. 2012. Genetic counseling and testing for FMR1 gene mutations: practice guidelines of the national society of genetic counselors. J Genet Couns 21:752-760.

Fragile X Alliance Inc. From http://www.fragilex.com.au/.

Fragile X Association of Australia. From http://fragilex.org.au/.

Fragile X Association of Australia. 2009. From http://fragilex.org.au/2009-fx-family-surveyaustnz-reports/. 
Fu YH, Kuhl DP, Pizzuti A, Pieretti M, Sutcliffe JS, Richards S, Verkerk AJ, Holden JJ, Fenwick RG, Jr., Warren ST, Oostra BA, Nelson DL, Caskey CT. 1991. Variation of the CGG repeat at the fragile X site results in genetic instability: resolution of the Sherman paradox. Cell 67:1047-1058.

Hagerman RJ, Berry-Kravis E, Kaufmann WE, Ono MY, Tartaglia N, Lachiewicz A, Kronk R, Delahunty C, Hessl D, Visootsak J, Picker J, Gane L, Tranfaglia M. 2009. Advances in the treatment of fragile X syndrome. Pediatrics 123:378-390.

Hagerman RJ, Leehey M, Heinrichs W, Tassone F, Wilson R, Hills J, Grigsby J, Gage B, Hagerman PJ. 2001. Intention tremor, parkinsonism, and generalized brain atrophy in male carriers of fragile X. Neurology 57:127-130.

Hersh JH, Saul RA, Committee on G. 2011. Health supervision for children with fragile X syndrome. Pediatrics 127:994-1006.

Hill MK, Archibald AD, Cohen J, Metcalfe SA. 2010. A systematic review of population screening for fragile X syndrome. Genet Med 12:396-410.

Human Genetics Society of Australasia. 2012. "Best Practice Fragile X Testing and Analysis Guidelines for Australasian Laboratories."

Kemper AR, Bailey DB, Jr. 2009. Pediatricians' knowledge of and attitudes toward fragile X syndrome screening. Acad Pediatrics 9:114-117.

Kraan CM, Hocking DR, Bradshaw JL, Georgiou-Karistianis N, Metcalfe SA, Archibald AD, Fielding J, Trollor J, Cohen J, Cornish KM. 2014a. Symbolic sequence learning is associated with cognitive-affective profiles in female FMR1 premutation carriers. Genes Brain Behav 13:385-393.

Kraan CM, Hocking DR, Georgiou-Karistianis N, Metcalfe SA, Archibald AD, Fielding J, Trollor J, Bradshaw JL, Cohen J, Cornish KM. 2014b. Impaired response inhibition is 
associated with self-reported symptoms of depression, anxiety, and ADHD in female FMR1 premutation carriers. Am J Med Genet Part B Neuropsychiatr Genet 165B:41-51.

Lachiewicz AM, Dawson DV, Spiridigliozzi GA. 2000. Physical characteristics of young boys with fragile $\mathrm{X}$ syndrome: reasons for difficulties in making a diagnosis in young males. Am J Med Genet 92:229-236.

Loesch DZ, Godler DE, Khaniani M, Gould E, Gehling F, Dissanayake C, Burgess T, Tassone F, Huggins R, Slater H, Choo KH. 2009A. Linking the FMR1 alleles with small CGG expansions with neurodevelopmental disorders: preliminary data suggest an involvement of epigenetic mechanisms. Am J Med Genet Part A 149A:2306-2310.

Loesch DZ, Khaniani MS, Slater HR, Rubio JP, Bui QM, Kotschet K, D'Souza W, Venn A, Kalitsis P, Choo AK, Burgess T, Johnson L, Evans A, Horne M. 2009B. Small CGG repeat expansion alleles of FMR1 gene are associated with parkinsonism. Clin Genet $76: 471-476$.

Medicare Benefits Schedule. From http://www.mbsonline.gov.au/internet/mbsonline/ publishing.nsf/Content/Home.

Nolin SL, Brown WT, Glicksman A, Houck GE, Jr., Gargano AD, Sullivan A, Biancalana V, Brondum-Nielsen K, Hjalgrim H, Holinski-Feder E, Kooy F, Longshore J, Macpherson J, Mandel JL, Matthijs G, Rousseau F, Steinbach P, Vaisanen ML, von Koskull H, Sherman SL. 2003. Expansion of the fragile X CGG repeat in females with premutation or intermediate alleles. Am J Hum Genet 72:454-464.

Nolin SL, Lewis FA, 3rd, Ye LL, Houck GE, Jr., Glicksman AE, Limprasert P, Li SY, Zhong N, Ashley AE, Feingold E, Sherman SL, Brown WT. 1996. Familial transmission of the FMR1 CGG repeat. Am J Hum Genet 59:1252-1261. 
Sherman S, Pletcher BA, Driscoll DA. 2005. Fragile X syndrome: diagnostic and carrier testing. Genet Med 7:584-587.

Sullivan AK, Marcus M, Epstein MP, Allen EG, Anido AE, Paquin JJ, Yadav-Shah M, Sherman SL. 2005. Association of FMR1 repeat size with ovarian dysfunction. Hum Reprod 20:402-412.

Tassone F, Iong KP, Tong T-H, Lo J, Gane LW, Berry-Kravis E, Nguyen D, Mu LY, Laffin J, Bailey DB. 2012. FMR1 CGG allele size and prevalence ascertained through newborn screening in the United States. Genome Med 4:100.

Victorian Clinical Genetics Services. Reproductive genetic carrier screening. 2009. From http://www.vcgs.org.au. 


\section{Legends}

\section{Figure 2A and B}

In both graphs, the horizontal axis is in yearly intervals until 20 years of age, then in 5 yearly intervals up to 90 years of age.

\section{Figure 2B}

In the age group greater than 20 years, there are 29 individuals (21males and 8 females) who received a FM result (shown in deep blue or dark grey). It is possible these individuals, in particular the males, might have been diagnosed clinically with FXS much earlier. If these 29 individuals are excluded, then the median age at testing for the remaining 39 individuals $<20$ years of age with a FM result is 3.3 years: males 2.2 years, and females 6.8 years.

\section{Table I}

${ }^{a}$ Predominantly requesting more conclusive testing, ie Southern blot. The speciality of the health practitioner requesting the initial test from the other pathology laboratories could not be determined

${ }^{\mathrm{b}}$ Other specialties included: cardiologist $(\mathrm{n}=1)$, dermatologist $(\mathrm{n}=1)$, emergency medicine $(n=2)$, gastroenterologist $(n=2)$, haematologist $(n=4)$, nephrologist $(n=1)$, oncologist $(n=1)$, ophthalmologist $(n=3)$, otorhinologist $(n=1)$, radiologist $(n=1)$, rheumatologist $(n=1)$

${ }^{\mathrm{c}}$ The speciality of the requesting health practitioner attending these hospital-based clinics could not be determined

d There were an additional 259 tests ordered for whom the specialty of the requesting doctor could not be determined, so the overall number of individual health practitioners ordering a test is somewhat higher than this.

\section{Table II}

${ }^{a}$ Other health practitioners included pathologists, obstetricians/gynecologists, an endocrinologist, a psychiatrist, a neurologist, or specialty could not be determined.

${ }^{\mathrm{b}}$ This median age includes 21 males $>20$ years of age (see also Figure $2 \mathrm{~B}$ ). If these individuals are excluded, then the median age at testing for males $<20$ years of age is 2.2 years. 
${ }^{\mathrm{c}}$ No family history of FXS noted on the request form; clinical indications typically included developmental delay, intellectual disability, autism-like features

${ }^{\mathrm{d}}$ Known family history of FXS noted on the request form

${ }^{\mathrm{e}}$ No family history of FXS noted on the request form

${ }^{\mathrm{f}}$ Known family history of FXS noted on the request form

\section{Table III}

${ }^{a}$ Other health practitioners included obstetrician/gynecologists, pathologists, neurologists, an endocrinologist, a surgeon or specialty could not be determined

${ }^{\mathrm{b}}$ No family history of FXS noted on the request form; clinical indications typically included developmental delay, intellectual disability, autism-like features

${ }^{\mathrm{c}}$ Known family history of FXS noted on the request form

${ }^{\mathrm{d}}$ No family history of FXS noted on the request form

${ }^{\mathrm{e}}$ Requested by neurologists

${ }^{\mathrm{f}}$ Requested by a neurologist, a pathologist, an endocrinologist and obstetrician/gynecologists $(\mathrm{n}=6)$ 

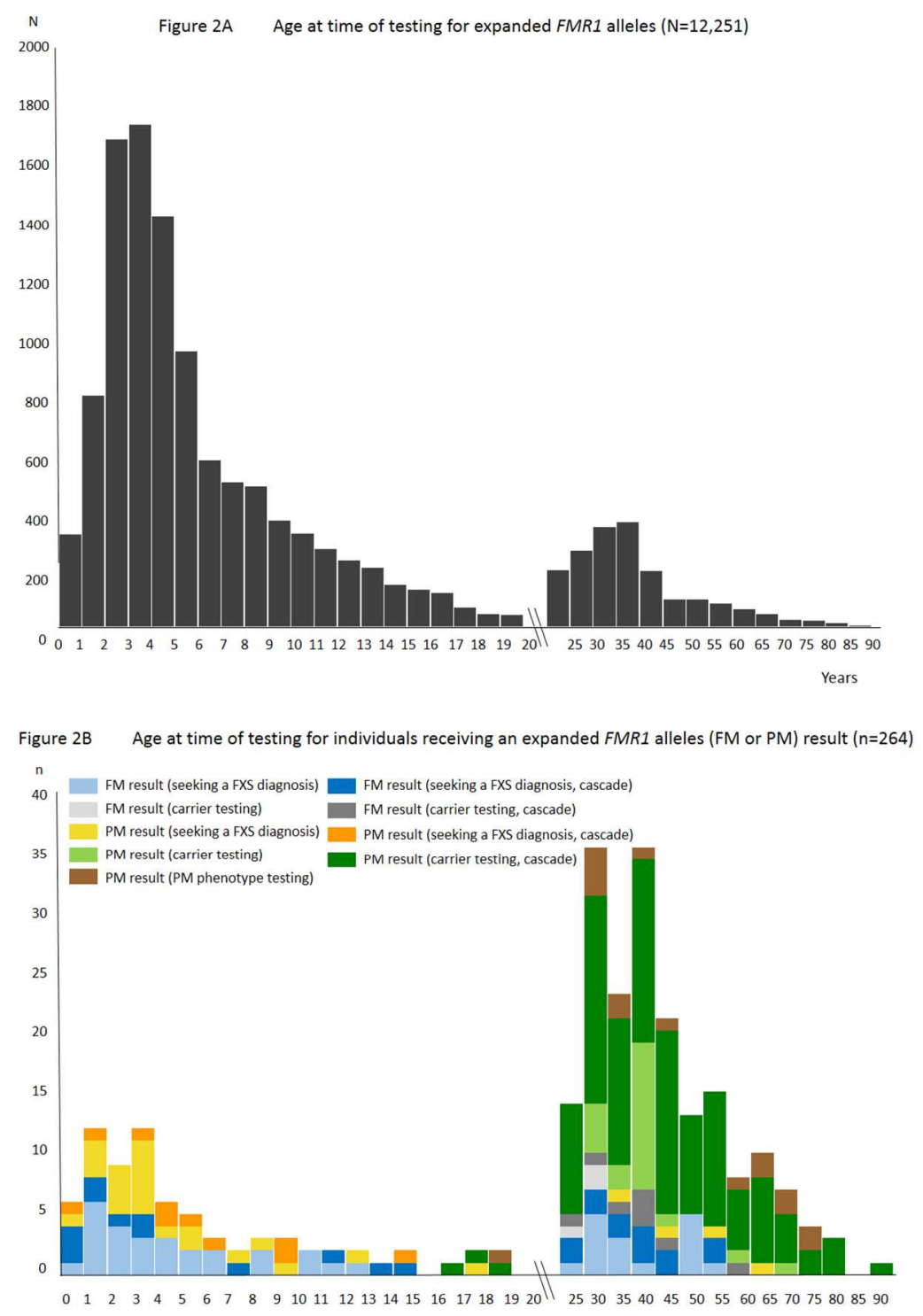
Table I. Health practitioners requesting FMR1 genetic test between January 2003 and December 2009

\begin{tabular}{|c|c|c|c|c|c|}
\hline $\begin{array}{c}\text { Health } \\
\text { practitioner } \\
\text { specialty }\end{array}$ & $\begin{array}{l}\text { Number of } \\
\text { health } \\
\text { practitioners } \\
\text { requesting } 1 \\
\text { test only }\end{array}$ & $\begin{array}{l}\text { Number of } \\
\text { health } \\
\text { practitioners } \\
\text { requesting } \\
2-10 \text { tests }\end{array}$ & $\begin{array}{l}\text { Number of } \\
\text { health } \\
\text { practitioners } \\
\text { requesting } \\
>10 \text { tests }\end{array}$ & $\begin{array}{c}\text { Total } \\
\text { number of } \\
\text { individual } \\
\text { health } \\
\text { practitioners }\end{array}$ & $\begin{array}{c}\text { Mean } \\
\text { number of } \\
\text { tests } \\
\text { requested } \\
\text { by health } \\
\text { practitioner } \\
\text { who } \\
\text { ordered } \\
>10 \text { tests }\end{array}$ \\
\hline Pediatrician & 47 & 101 & 151 & 299 & 52.3 \\
\hline $\begin{array}{l}\text { General } \\
\text { practitioner }\end{array}$ & 362 & 113 & 18 & 493 & 20.3 \\
\hline $\begin{array}{l}\text { Clinical } \\
\text { geneticist/ } \\
\text { genetic } \\
\text { counselor }\end{array}$ & 4 & 15 & 14 & 33 & 55.6 \\
\hline $\begin{array}{l}\text { Obstetrician/ } \\
\text { gynecologist }\end{array}$ & 30 & 25 & 10 & 65 & 18.3 \\
\hline Neurologist & 23 & 15 & 2 & 40 & 26 \\
\hline Pathologist $^{\mathrm{a}}$ & 6 & 10 & 18 & 34 & 49.4 \\
\hline Endocrinologist & 7 & 4 & 1 & 12 & 18.3 \\
\hline $\begin{array}{l}\text { Psychiatrist/ } \\
\text { psychologist }\end{array}$ & 16 & 4 & 1 & 21 & 22 \\
\hline Surgeon & 10 & 2 & 1 & 13 & 13 \\
\hline $\begin{array}{l}\text { Other } \\
\text { specialties }\end{array}$ & 14 & 4 & 0 & 18 & 0 \\
\hline Hospital clinic $^{c}$ & 16 & 2 & 2 & 20 & 14 \\
\hline Total & 535 & 295 & 218 & $1048^{d}$ & \\
\hline
\end{tabular}


Table II. Median age at testing for individuals with a full mutation (FM) result identified between January 2003 and December 2009

\begin{tabular}{|c|c|c|c|c|c|}
\hline \multirow{2}{*}{$\begin{array}{l}\text { Individuals with a } \\
\text { full mutation } \\
\text { (FM) result }\end{array}$} & \multicolumn{5}{|c|}{ Requesting health practitioner } \\
\hline & All health practitioners & Pediatrician & General practitioner & $\begin{array}{l}\text { Genetic health } \\
\text { professionals }\end{array}$ & Other $^{\mathrm{a}}$ \\
\hline $\begin{array}{l}\text { Total individuals } \\
\text { tested }\end{array}$ & $\begin{array}{c}20.7 \text { years } \\
\text { (range }=<0.1-58.5 \text { years) } \\
\mathrm{n}=79\end{array}$ & $\begin{array}{c}3.2 \text { years } \\
\text { (range }=1.0-38.1 \text { years) } \\
\mathrm{n}=28\end{array}$ & $\begin{array}{c}34.2 \text { years } \\
(\text { range }=11.8-52.3 \text { years }) \\
\mathrm{n}=21\end{array}$ & $\begin{array}{c}31.9 \text { years } \\
\text { (range }=3.3-58.5 \text { years) } \\
\mathrm{n}=14\end{array}$ & $\begin{array}{c}27.6 \text { years } \\
\text { (range }=<0.1-54.8 \text { years) } \\
\mathrm{n}=16\end{array}$ \\
\hline - males & $\begin{array}{c}12.4 \text { years }^{\mathrm{b}} \\
\text { (range }=0.1-54.8 \text { years) } \\
\mathrm{n}=46\end{array}$ & $\begin{array}{c}2.4 \text { years } \\
\text { (range }=1.0-8.8 \text { years) } \\
\mathrm{n}=18\end{array}$ & $\begin{array}{c}35.9 \text { years } \\
\text { (range }=14.8-52.7 \text { years }) \\
n=16\end{array}$ & $\begin{array}{c}12.4 \text { years } \\
\text { (range }=3.3-31.2 \text { years) } \\
\mathrm{n}=4\end{array}$ & $\begin{array}{c}28.3 \text { years } \\
\text { (range }=0.1-54.8 \text { years) } \\
\mathrm{n}=8\end{array}$ \\
\hline - females & $\begin{array}{c}23.8 \text { years } \\
(\text { range }=<0.1-58.5 \text { years }) \\
n=33\end{array}$ & $\begin{array}{c}6.1 \text { years } \\
\text { (range }=1.8-38.1 \text { years) } \\
n=10\end{array}$ & $\begin{array}{c}21.6 \text { years } \\
\text { (range }=11.8-43.8 \text { years) } \\
\mathrm{n}=5\end{array}$ & $\begin{array}{c}36.1 \text { years } \\
\text { (range }=20.7-58.5 \text { years) } \\
n=10\end{array}$ & $\begin{array}{c}27.4 \text { years } \\
\text { (range }=<0.1-38.3 \text { years) } \\
n=8\end{array}$ \\
\hline $\begin{array}{l}\begin{array}{l}\text { Seeking diagnosis } \\
\text { of } \mathrm{FXS}^{\mathrm{c}}\end{array} \\
\quad \text { - males } \\
\end{array}$ & $\begin{array}{c}4.3 \text { years } \\
\text { (range }=1.0-54.8 \text { years) } \\
\mathrm{n}=31\end{array}$ & $\begin{array}{c}2.1 \text { years } \\
\text { (range }=1.0-8.8 \text { years) } \\
\mathrm{n}=16\end{array}$ & $\begin{array}{c}34.4 \text { years } \\
\text { (range }=24.0-48.9 \text { years) } \\
n=8\end{array}$ & $\begin{array}{c}11.0 \text { years } \\
n=1\end{array}$ & $\begin{array}{c}38.3 \text { years } \\
\text { (range }=2.4-54.8 \text { years) } \\
\mathrm{n}=6\end{array}$ \\
\hline - females & $\begin{array}{c}9.4 \text { years } \\
\text { (range }=4.3-38.3 \text { years) } \\
n=12\end{array}$ & $\begin{array}{c}6.1 \text { years } \\
\text { (range }=4.3-10.4 \text { years) } \\
\mathrm{n}=6\end{array}$ & $\begin{array}{c}14.0 \text { years } \\
n=1\end{array}$ & $\mathrm{n}=0$ & $\begin{array}{c}27.3 \text { years } \\
\text { (range }=6.6-38.8 \text { years) } \\
\mathrm{n}=5\end{array}$ \\
\hline $\begin{array}{l}\text { Seeking diagnosis } \\
\text { of FXS (cascade } \\
\text { testing) }{ }^{\mathrm{d}} \\
\quad \text { - males }\end{array}$ & $\begin{array}{c}28.7 \text { years } \\
\text { (range }=0.1-52.7 \text { years) } \\
\mathrm{n}=15\end{array}$ & $\begin{array}{c}3.0 \text { years } \\
\text { (range }=2.6-3.3 \text { years) } \\
\mathrm{n}=2\end{array}$ & $\begin{array}{c}38.5 \text { years } \\
\text { (range }=14.8-52.7 \text { years) } \\
n=8\end{array}$ & $\begin{array}{c}13.8 \text { years } \\
\text { (range }=3.3-31.2 \text { years) } \\
n=3\end{array}$ & $\begin{array}{c}0.3 \text { years } \\
\text { (range }=0.1-0.5 \text { years) } \\
\mathrm{n}=2\end{array}$ \\
\hline - females & $\begin{array}{c}16.7 \text { years } \\
\text { (range }=<0.1-43.8 \text { years) } \\
\mathrm{n}=10\end{array}$ & $\begin{array}{c}1.8 \text { years } \\
\text { (range }=1.8-8.0 \text { years) } \\
\mathrm{n}=3\end{array}$ & $\begin{array}{c}23.0 \text { years } \\
\text { (range }=11.8-43.8 \text { years) } \\
n=4\end{array}$ & $\begin{array}{c}36.1 \text { years } \\
\text { (range }=33.0-39.2 \text { years) } \\
n=2\end{array}$ & $\begin{array}{c}<0.1 \text { years } \\
\mathrm{n}=1\end{array}$ \\
\hline $\begin{array}{l}\begin{array}{l}\text { Seeking carrier } \\
\text { status }^{\text {e }} \\
\quad \text { - females }\end{array}\end{array}$ & $\begin{array}{c}27.6 \text { years } \\
\text { (range }=27.6-27.8 \text { years) } \\
n=3\end{array}$ & $\mathrm{n}=0$ & $\mathrm{n}=0$ & $\begin{array}{c}23.8 \text { years } \\
\mathrm{n}=1\end{array}$ & $\begin{array}{c}27.7 \text { years } \\
\text { (range }=27.6-27.8 \text { years) } \\
n=2\end{array}$ \\
\hline $\begin{array}{l}\text { Seeking carrier } \\
\text { status (cascade } \\
\text { testing) } \\
\quad \text { - females }\end{array}$ & $\begin{array}{c}38.8 \text { years } \\
\text { (range }=20.7-58.5 \text { years) } \\
\mathrm{n}=8\end{array}$ & $\begin{array}{c}38.0 \text { years } \\
n=1\end{array}$ & $\mathrm{n}=0$ & $\begin{array}{c}39.4 \text { years } \\
\text { (range }=20.7-58.5 \text { years) } \\
n=7\end{array}$ & $\mathrm{n}=0$ \\
\hline
\end{tabular}




\section{Page 29 of 31}

American Journal of Medical Genetics: Part A 
Table III. Median age at testing for individuals with a premutation (PM) result identified between January 2003 and December 2009

\begin{tabular}{|c|c|c|c|c|c|}
\hline \multirow{2}{*}{$\begin{array}{l}\text { Individuals with a } \\
\text { premutation (PM) } \\
\text { result }\end{array}$} & \multicolumn{5}{|c|}{ Requesting health practitioner } \\
\hline & All health practitioners & Pediatricians & General practitioners & $\begin{array}{l}\text { Genetic health } \\
\text { professionals }\end{array}$ & Other $^{\mathrm{a}}$ \\
\hline \multirow{4}{*}{ Total tested } & $\begin{array}{c}36.1 \text { years } \\
\text { (range }=<0.1-89.9 \text { years) }\end{array}$ & $\begin{array}{c}7.3 \text { years } \\
(\text { range }=1.4-42.3 \text { years })\end{array}$ & $\begin{array}{c}36.1 \text { years } \\
(\text { range }=1.4-71.1 \text { years })\end{array}$ & $\begin{array}{c}39.9 \text { years } \\
\text { (range }=3.4-89.9 \text { years) }\end{array}$ & $\begin{array}{c}33.5 \text { years } \\
\text { (range }=<0.1-73.7 \text { years) }\end{array}$ \\
\hline & $\mathrm{n}=185$ & $n=25$ & $\mathrm{n}=37$ & $\mathrm{n}=93$ & $n=30$ \\
\hline & $\begin{array}{c}33.2 \text { years } \\
(\text { range }=<0.1-73.7 \text { years) }\end{array}$ & $\begin{array}{c}4.3 \text { years } \\
(\text { range }=1.4-39.3 \text { years })\end{array}$ & $\begin{array}{c}25.6 \text { years } \\
(\text { range }=1.4-70.6 \text { years })\end{array}$ & $\begin{array}{c}45.3 \text { years } \\
(\text { range }=3.4-70.7 \text { years })\end{array}$ & $\begin{array}{c}31.9 \text { years } \\
(\text { range }=<0.1-73.7 \text { years })\end{array}$ \\
\hline & $\mathrm{n}=62$ & $\mathrm{n}=12$ & $\mathrm{n}=21$ & $\mathrm{n}=23$ & $\mathrm{n}=6$ \\
\hline - females & $\begin{array}{c}36.4 \text { years } \\
\text { (range }=1.3-89.9 \text { years) } \\
n=123\end{array}$ & $\begin{array}{c}22.4 \text { years } \\
(\text { range }=2.5-42.3 \text { years }) \\
n=13\end{array}$ & $\begin{array}{c}43.1 \text { years } \\
\text { (range }=16.8-71.1 \text { years) } \\
n=16\end{array}$ & $\begin{array}{c}39.6 \text { years } \\
\text { (range }=9.8-89.9 \text { years) } \\
n=70\end{array}$ & $\begin{array}{c}33.5 \text { years } \\
\text { (range }=1.3-64.5 \text { years) } \\
n=24\end{array}$ \\
\hline \multirow[t]{2}{*}{$\begin{array}{l}\text { Seeking diagnosis of } \\
\begin{array}{l}\text { FXS }^{\text {b }} \\
\end{array}\end{array}$} & $\begin{array}{c}3.8 \text { years } \\
\text { (range }=1.0-61.5 \text { years) } \\
n=21\end{array}$ & $\begin{array}{c}3.5 \text { years } \\
(\text { range }=1.4-8.7 \text { years }) \\
n=10\end{array}$ & $\begin{array}{c}9.4 \text { years } \\
\text { (range }=1.4-52.0 \text { years) } \\
n=5\end{array}$ & $\begin{array}{c}19.9 \text { years } \\
\text { (range }=3.4-61.5 \text { years) } \\
n=4\end{array}$ & $\begin{array}{c}1.8 \text { years } \\
(\text { range }=1.0-2.7 \text { years }) \\
n=2\end{array}$ \\
\hline & $\begin{array}{c}3.2 \text { years } \\
\text { (range }=1.4-17.4 \text { years) } \\
n=5\end{array}$ & $\begin{array}{c}7.8 \text { years } \\
\text { (range }=2.5-17.4 \text { years) } \\
n=4\end{array}$ & $\mathrm{n}=0$ & $\mathrm{n}=0$ & $\begin{array}{c}1.4 \text { years } \\
n=1\end{array}$ \\
\hline \multirow[t]{2}{*}{$\begin{array}{l}\text { Seeking diagnosis of } \\
\text { FXS (cascade testing) } \\
\text { - males }\end{array}$} & $\begin{array}{c}4.1 \text { years } \\
(\text { range }=<0.1-9.4 \text { years }) \\
n=5\end{array}$ & $\mathrm{n}=0$ & $\begin{array}{c}6.4 \text { years } \\
\text { (range }=3.8-9.4 \text { years) } \\
n=3\end{array}$ & $\begin{array}{c}\text { 4.1 years } \\
n=1\end{array}$ & $\begin{array}{c}<0.1 \text { years } \\
n=1\end{array}$ \\
\hline & $\begin{array}{c}5.4 \text { years } \\
(\text { range }=1.3-14.0 \text { years) } \\
n=5\end{array}$ & $\begin{array}{c}4.9 \text { years } \\
\text { (range }=4.4-5.4 \text { years) } \\
n=2\end{array}$ & $\mathrm{n}=0$ & $\begin{array}{c}11.9 \text { years } \\
\text { (range }=9.8-14.0 \text { years) } \\
n=2\end{array}$ & $\begin{array}{c}1.3 \text { years } \\
n=1\end{array}$ \\
\hline \multirow[t]{3}{*}{$\begin{array}{l}\text { Seeking PM carrier } \\
\text { status }^{\mathrm{d}} \\
\\
\end{array}$} & $\begin{array}{c}37.9 \text { years } \\
\text { (range }=26.0-76.3 \text { years) } \\
n=7\end{array}$ & $\begin{array}{c}39.3 \text { years } \\
n=1\end{array}$ & $\begin{array}{c}40.9 \text { years } \\
\text { (range }=26.0-55.8 \text { years) } \\
n=2\end{array}$ & $\begin{array}{c}37.0 \text { years } \\
\text { (range }=34.8-67.3 \text { years) } \\
n=4\end{array}$ & $\mathrm{n}=0$ \\
\hline & $\begin{array}{c}36.0 \text { years } \\
\text { (range }=26.7-41.6 \text { years) } \\
n=14\end{array}$ & 27.6 years & $\begin{array}{c}37.1 \text { years } \\
\text { (range }=36.0-38.9 \text { years) } \\
n=3\end{array}$ & $\begin{array}{c}34.0 \text { years } \\
\text { (range }=29.8-38.2 \text { years) } \\
n=2\end{array}$ & $\begin{array}{c}36.0 \text { years } \\
\text { (range }=26.7-41.6 \text { years) } \\
n=8\end{array}$ \\
\hline & $\begin{array}{c}44.5 \text { years } \\
\text { (range }=21.3-60.9 \text { years) } \\
n=24\end{array}$ & $\begin{array}{c}33.6 \text { years } \\
n=1\end{array}$ & $\begin{array}{c}28.5 \text { years } \\
\text { (range }=21.3-70.6 \text { years) } \\
\mathrm{n}=11\end{array}$ & $\begin{array}{c}49.9 \text { years } \\
\text { (range }=29.3-70.9 \text { years) } \\
n=12\end{array}$ & $\mathrm{n}=0$ \\
\hline
\end{tabular}




\section{Page 31 of 31}

American Journal of Medical Genetics: Part A

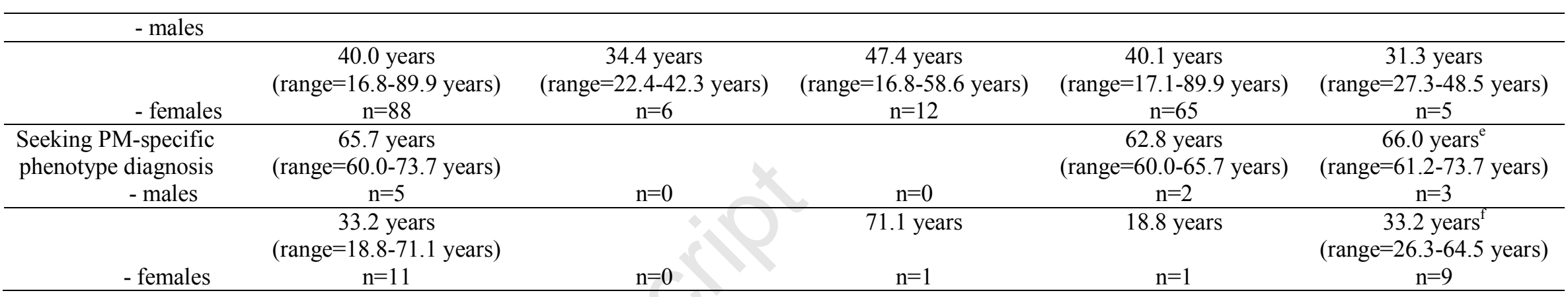




\section{University Library}

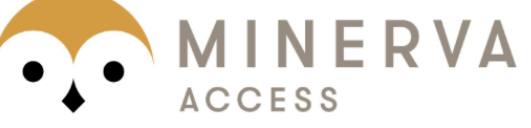

A gateway to Melbourne's research publications

Minerva Access is the Institutional Repository of The University of Melbourne

\section{Author/s:}

Cotter, M;Archibald, AD;McClaren, BJ;Burgess, T;Francis, D;Hills, L;Martyn, M;Oertel, R;Slater, H;Cohen, J;Metcalfe, SA

Title:

Clinical Audit of Genetic Testing and Referral Patterns for Fragile X and Associated Conditions

Date:

2016-06-01

Citation:

Cotter, M., Archibald, A. D., McClaren, B. J., Burgess, T., Francis, D., Hills, L., Martyn, M., Oertel, R., Slater, H., Cohen, J. \& Metcalfe, S. A. (2016). Clinical Audit of Genetic Testing and Referral Patterns for Fragile $X$ and Associated Conditions. AMERICAN JOURNAL OF MEDICAL GENETICS PART A, 170 (6), pp.1439-1449. https://doi.org/10.1002/ajmg.a.37603.

Persistent Link:

http://hdl.handle.net/11343/290962 